\title{
Encapsulation of Lycopene Using Spray-Drying and Molecular Inclusion Processes
}

\author{
Itaciara Larroza Nunes and Adriana Zerlotti Mercadante* \\ Departamento de Ciência de Alimentos; Faculdade de Engenharia de Alimentos; Universidade Estadual de \\ Campinas; itaciara@yahoo.com; azm@fea.unicamp.br; C.P. 6121; 13083-862; Campinas - SP - Brasil
}

\begin{abstract}
This study aimed to obtain encapsulated lycopene in a powder form, using either spray-drying or molecular inclusion with $\beta$-cyclodextrin ( $\beta$-CD) followed by freeze-drying. The encapsulation efficiency using spray-drying ranged from 94 to $96 \%$, with an average yield of $51 \%$, with microcapsules showing superficial indentations and lack of cracks and breakages. Lycopene- $\beta$-CD complexes were only formed at a molar ratio of 1:4, and irregular structures of different sizes that eventually formed aggregates, similar to those of $\beta$ - $C D$, were observed after freezedrying. About $50 \%$ of the initial lycopene did not form complexes with $\beta$-CD. Lycopene purity increased from 96.4 to $98.1 \%$ after spray-drying, whereas lycopene purity decreased from 97.7 to $91.3 \%$ after complex formation and freeze-drying. Both the drying processes yielded pale-pink, dry, free-flowing powders.
\end{abstract}

Key words: Lycopene, encapsulation, spray-drying, gum arabic, inclusion complex, $\beta$-cyclodextrin

\section{INTRODUCTION}

Carotenoids show several beneficial functions to human beings; besides these pigments are largely used as colorant in foods, drinks, cosmetics and animal feed, mainly poultry and fish. In addition, the food and cosmetic industries are seeking to substitute the artificial colorants by natural ones (Britton et al., 1995). In recent times, the interest on lycopene has increased, due to the association between consumption of lycopene-rich foods, such as tomato and its products, and high levels of lycopene in plasma with a decreased risk of prostate cancer development (Van Den Berg et al., 2000; Giovannucci, 2002; Venkateswaran et al., 2004).

The properties, actions and functions of carotenoids, including lycopene, are closely related to their chemical structure. The polyenic chain is responsible both for visible light absorption and for high molecule reactivity. Most carotenoids in the nature are found in the trans configuration (Mercadante and Egeland, 2004) due to its higher stability compared to the cis isomer. However, during the processing and storage, carotenoids can easily rearrange in different geometric isomers and also be oxidized, with the consequent decrease or loss of the colorant and biological properties.

The most applied alternative to increase stability of carotenoids and to allow their incorporation in hydrophilic environment is the microencapsulation technique, which provides a physical barrier protecting the pigment. Among the available microencapsulation techniques, the most used process is spray-drying. Maltodextrins (MD) of different dextrose equivalent (DE) were employed alone for spray-drying encapsulation of carrot

\footnotetext{
${ }^{*}$ Author for correspondence
} 
juice (Wagner and Warthesen, 1995) and all-trans$\beta$-carotene (Desobry et al., 1997) or in combination with other sugars for all-trans- $\beta$ carotene (Desobry et al., 1999) and bixin (Barbosa et al., 2005) encapsulation. Other polysaccharide largely used for spray-drying microencapsulation is gum arabic, either alone (Matioli and Rodriguez-Amaya, 2002), or as a mixture with MD (Leach et al., 1998; Matioli and RodriguezAmaya, 2002) or with sucrose (Barbosa et al., 2005).

Another possibility is the use of cyclodextrins (CD), which possess a hydrophobic center that allows the physical-chemical interaction with carotenoids, and formation of stable inclusion complexes. Two methods of complex preparation, known as solid and liquid mixture, are available for carotenoid inclusion into $\mathrm{CD}$ at diverse molar ratios. Inclusion of trans- $\beta$-carotene into $\beta$ - and $\gamma$ $\mathrm{CD}$ (molar ratio 1:4) by solid mixture was reported by Mele et al. (1998). Similar technique was used to prepare lycopene with $\alpha$ - and $\beta$-CD (Mele et al., 2002). Canthaxanthin, $\beta$-carotene, and lutein complexation with $\beta-C D$ was also carried out by the solid mixture method at a molar ratio of 1:10, respectively (Lacrajan et al., 2001). Polyakov et al. (2004) prepared complexes as solid mixture using $\beta$-carotene and $3 \beta$-carotene synthetic derivatives and $\beta$-CD complexes at molar ratios of $1: 1$ and $1: 2$, respectively.

The liquid mixture method was employed by Pfitzner et al. (2000) to formulate carotenoids complexes. Dichloromethane solution of $\beta$ carotene, lycopene, lutein and zeaxanthin were separately stirred with methyl- $\beta-C D$ in ethanol. Lycopene, dissolved in acetone, with aqueous solutions of $\mathrm{CD}(\alpha-, \beta-$ or $\gamma$-CD) at molar ratios of 1:50, 1:100, 1:150, 1:200 and 1:250 was prepared by Matioli and Rodriguez-Amaya (2003); maximum inclusion was achieved with $\gamma-\mathrm{CD}$ at a molar ratio of 1:200. Recently, complexation was attained through a simple percolation of a chloroform/acetone solution of bixin on a column packed with 10-20 times amount of dry $\alpha-C D$ (Ling et al., 2005).

The aim of the present study was to obtain encapsulated lycopene in a powder form, evaluating the spray-drying and inclusion-freezedrying processes.

\section{MATERIAL AND METHODS}

\section{Lycopene preparation}

Lycopene crystals were obtained from the fresh tomatoes according to Nunes and Mercadante (2004). Briefly, the methodology consisted of four steps: (1) preliminary water removal with four 30minute extractions, each with $30 \mathrm{~mL}$ commercial ethanol with discard of the solvent, (2) four 120minute extractions with ethyl acetate, each extraction with a mass/volume ratio of 1:0.7, (3) complete solvent evaporation on a rotary evaporator and (4) crystallization from dichloromethane/ethanol (1:4), repeated twice.

\section{Encapsulation of lycopene by spray-dryer}

Gum arabic (Corn Products Brasil) and sucrose (8:2), total of $60 \mathrm{~g}$, were solubilized in $200 \mathrm{~mL}$ water at $45^{\circ} \mathrm{C}$ and kept under stirring until the temperature reached $30^{\circ} \mathrm{C}$. The microcapsules were prepared by dissolving lycopene crystals (15 $\mathrm{mg}$ ) in $20 \mathrm{~mL}$ dichloromethane, which was added to the polysaccharide solution and vigorously homogenized at $7000 \mathrm{rpm}$ for $30 \mathrm{~min}$ at room temperature. Distilled water $(80 \mathrm{~mL})$ was added to reach a $20 \%(\mathrm{w} / \mathrm{v})$ soluble solid solution, which was maintained under slow agitation during the spray-drying process. The spray-dryer (Lab Plant SD-04, United Kingdom) was operated at air flow rate of $30 \mathrm{~mL} / \mathrm{min}$, entrance and exit air temperatures of $170 \pm 2$ and $113 \pm 2^{\circ} \mathrm{C}$, respectively, air pressure of $5 \mathrm{kgf} / \mathrm{cm}^{2}$ and aspersion nozzle diameter of $0.7 \mathrm{~mm}$. The microcapsules were immediately stored, under $\mathrm{N}_{2}$, in a glass bottle at $-20^{\circ} \mathrm{C}$.

The encapsulation yield (EY) was calculated according to equation 1 .

$\% \mathrm{EY}=\frac{\mathrm{MSA} \times 100}{\mathrm{MSB}}$

where:

MSA = total mass of microcapsules obtained after encapsulation and MSB = total mass of solids before encapsulation.

The microencapsulation efficiency (ME) was calculated according to McNamee et al. (2001), as shown in equation 2 .

$$
\% \mathrm{ME}=\frac{(\mathrm{TL}-\mathrm{SL}) \times 100}{\mathrm{TL}}
$$

where:

$\mathrm{TL}=$ total lycopene and SL = surface lycopene. 


\section{Preparation of lycopene- $\beta-C D$ inclusion complex}

Lycopene crystals $(20 \mathrm{mg})$ were dissolved in dichloromethane and slowly added to $c a .10 \mathrm{~mL}$ of an aqueous $\beta$-CD (Sigma) solution with $0.2 \%$ Tween 20 at $35^{\circ} \mathrm{C}$, under vigorous homogenization until the solution reached room temperature. After overnight storage at $-18^{\circ} \mathrm{C}, 250 \mathrm{~mL}$ of water at $35^{\circ} \mathrm{C}$ was added, followed by filtration to retain not complexed material. The filtrate, containing the lycopene complex, was freeze-dried to obtain the powder. Molar ratios of 1:1 and 1:4 $(\mathrm{w} / \mathrm{w})$ of lycopene- $\beta-C D$ were tested. Lycopene not complexed into the $\mathrm{CD}$, e.g., lycopene that remained on the filter was dissolved in dichloromethane and dried in a rotary evaporator $\left(\mathrm{T}<38^{\circ} \mathrm{C}\right)$.

\section{Lycopene determination}

A specific method for determination of total and surface lycopene in the gum arabic/sucrose microcapsules was developed, based on the conditions described by Wagner and Warthesen (1995) for carotenoid extraction from encapsulated carrot juice. Lycopene microcapsules $(0.3 \mathrm{~g})$ were dispersed in distilled water $(5 \mathrm{~mL})$ and $7.5 \mathrm{~mL}$ of methanol was slowly added in order to break the microcapsules under vortex agitation. After adding $7.5 \mathrm{~mL}$ of dichloromethane, the mixture was gently stirred, transferred to a separation funnel and two more extractions, with $3 \mathrm{~mL}$ water, $5 \mathrm{~mL}$ methanol and $5 \mathrm{~mL}$ dichloromethane, were carried out. After addition of anhydrous sodium sulfate to the combined dichloromethane phase, which contained lycopene, the solvent was completely removed in a rotary evaporator $\left(\mathrm{T}<38^{\circ} \mathrm{C}\right)$. Surface lycopene was extracted from $0.5 \mathrm{~g}$ of microcapsules with $5 \mathrm{~mL}$ dichloromethane by vortex agitation and centrifugation $(3000 \mathrm{rpm}$ during $10 \mathrm{~min}$ ). The organic solvent was removed and another extraction with $5 \mathrm{~mL}$ dichloromethane was carried out. In order to separate the remained gum, the combined dichloromethane phase was further centrifuged at $4000 \mathrm{rpm}$ for $7 \mathrm{~min}$ and completely evaporated as previously described. In case the organic phase remained turbid, it was filtrated using a $0.22 \mu \mathrm{m}$ Millipore membrane.

Total lycopene from the powder $(0.01 \mathrm{~g})$ obtained by inclusion and freeze-drying was extracted with $2 \mathrm{~mL}$ dichloromethane by vortex agitation. Two more extractions with the same amount of dichloromethane were carried out, followed by evaporation of the combined organic phase.

Independently of the extraction method, dried lycopene was dissolved in petroleum ether, and quantified in a spectrophotometer at $470 \mathrm{~nm}$, using an absorption coefficient $\left(\mathrm{A}_{1 \mathrm{~cm}}^{1 \%}\right)$ of 3450 (Davies, 1976). The analysis was carried out in duplicate.

\section{Microstructure}

The morphology of lycopene microcapsules with gum arabic/sucrose, as well as of both freeze-dried $\beta-C D$ and lycopene- $\beta-C D$ complex was evaluated by scanning electronic microscopy (SEM) (JEOL, T-300 model, Japan) using an acceleration voltage of $10 \mathrm{kV}$. Samples were fixed in stubs containing a double-faced adhesive metallic tape and coated with gold in a Balzers evaporator (SCD 050, Austria) for $75 \mathrm{~s}$, with a current of $40 \mathrm{~mA}$.

\section{HPLC analysis}

The purity of lycopene, either as crystal, spraydried lycopene microcapsule or lycopene- $\beta-C D$ freeze-dried complex, was verified by HPLC. The analysis was carried out using a Waters HPLC system equipped with a photo-diode array detector (Waters, model 996). The equipment also included an on line degasser, a Rheodyne injection valve with a $20 \mu \mathrm{L}$ loop and an external oven. Data acquisition and processing were performed using the Millenium Waters software. The chromatograms were processed at $470 \mathrm{~nm}$ and the spectra were obtained between 250 and $600 \mathrm{~nm}$.

Separation of lycopene from spray-dried microcapsules was achieved on a polymeric YMC $\mathrm{C}_{30}$ column $(3 \mu \mathrm{m}, 250 \times 4.6 \mathrm{~mm})$ with $\mathrm{MeOH}$ $(0.1 \%$ triethylamine (TEA))/t-butyl methyl ether (TBME) $(1: 1 \mathrm{v} / \mathrm{v})$ at $1 \mathrm{~mL} / \mathrm{min}$ and column temperature set at $33^{\circ} \mathrm{C}$, whereas separation of lycopene from the $\beta$-CD complex was carried out on a monomeric $\mathrm{C}_{18}$ Novapack $(4 \mu \mathrm{m}, 300 \times 3.9$ $\mathrm{mm})$ column using as mobile phase a linear gradient of $\mathrm{MeOH}(0.1 \%$ TEA)/ethyl acetate (EtOAc) $/ \mathrm{H}_{2} \mathrm{O}$ from 8:1:1 to 7:3:0 (v/v) in $20 \mathrm{~min}$ at $1 \mathrm{~mL} / \mathrm{min}$ and temperature set at $29^{\circ} \mathrm{C}$. Both conditions were previously evaluated by Nunes and Mercadante (2006).

The lycopene isomers were identified, in both the columns, by comparison of the spectra features and elution order with data from literature (Hengartner et al.; 1992; Mercadante et al., 1999; Nunes and Mercadante, 2004) and with authentic standards of all-trans-, 5-cis-, 9-cis- and 13-cis- 
lycopene from DSM Nutritional Products (Switzerland).

All solvents were HPLC grade, previously filtered in a Millipore system with $0.45 \mu \mathrm{m}$ membrane. All the samples were also filtered with a $0.22 \mu \mathrm{m}$ membrane before injection.

\section{RESULTS AND DISCUSSION}

\section{Encapsulation by spray-drying process}

The drying process yield strongly depends on the equipment configuration, whilst the microencapsulation efficiency is related to the physico-chemical characteristics of both the core and wall material. Due to these facts, the yield of the spray-drying microencapsulation (EY) is not reported in most of the studies.

The average EY obtained in the present study by spray-drying was $51 \pm 1 \%$. Chen and Tang (1998) reported $67 \%$ of yield for carrot pulp encapsulation using spray-dryer (Niro Atomizer Co., Denmark), with sucrose/gelatin $(3.5: 2.5, \mathrm{p} / \mathrm{p})$ at $15 \%$ of total soluble solids, and inlet and exit air temperatures of $135-145$ and $90-100^{\circ} \mathrm{C}$, respectively. The lower yield obtained in the present study could be related either to the higher inlet air temperature $\left(170 \pm 2^{\circ} \mathrm{C}\right)$, which could contribute to sucrose caramelization or to equipment design differences. No comparison between microcapsules moisture contents could be done since this characteristic was not determined in both the studies.

In the present study, the microencapsulation efficiency ranged from 94 to $96 \%$, values much higher than those found in literature, also using spray-drying process. Among maltodextrins with different DE, the highest efficiency was obtained with maltodextrin $4 \mathrm{DE}$ for $\alpha-(89 \%)$ and $\beta$ carotene (87\%) (Wagner and Warthesen, 1995). Desobry et al. $(1997,1999)$ reported an efficiency of $62 \pm 2$ and of $78 \%$ for trans- $\beta$-carotene encapsulated respectively with maltodextrin $25 \mathrm{DE}$ and maltodextrin 4 DE/glucose (82:18). The maximum efficiency of $86 \%$ was obtained for bixin encapsulated with gum arabic/sucrose (95:5), whereas with maltodextrin $20 \mathrm{DE}$ this value was $54 \%$, increasing to $75 \%$ with addition of an emulsifier to maltodextrin (Barbosa et al., 2005). In conclusion, since the efficiency found in the present work was higher than those obtained in the literature, gum arabic could be considered an excellent choice as wall material for lycopene encapsulation by spray-drying process.

\section{Encapsulation by molecular inclusion lycopene- $\beta$-CD complex}

When lycopene and $\beta-\mathrm{CD}$, at a molar ratio of $1: 4$, were encapsulated according to the solid mixture method reported by Mele et al. (2002), no formation of the complex lycopene- $\beta-C D$ was observed. However, the same authors (Mele et al., 2002) reported the complex formation using lycopene and $\alpha$ - and $\beta-C D$ with a molar ratio of $1: 4$. On the other hand, in the present study, the complex lycopene- $\beta-C D$ was formed using the liquid method, resulting in a translucid pink solution. At a molar ratio of $1: 4$, about $50 \%$ of the added lycopene remained on the filter, whereas when a molar ratio of 1:1 was used, there was no formation of the complex, being all lycopene retained on the filter and the resulted solution stayed transparent. Matioli and Rodriguez-Amaya (2003) prepared the complexes lycopene-CDs in liquid form, using a molar ratio of 1:50 to 1:200, values much greater than those used in this study.

\section{Micrographs}

The microcapsules obtained with gum arabic by spray-drying showed a rounded external surface containing characteristic dents and no apparent cracks or porosity (Fig. 1a and 1b), aspects indicative of good protection of the core material. This morphology was also observed for gum arabic microcapsules of monoterpenes (Bertolini et al., 2001) and of bixin (Barbosa et al., 2005). The indented surface of the microcapsules made with gum arabic could be attributed to the spray-drying process, which caused shrinkage of particles during the drying and cooling stages (Sheu and Rosenberg, 1998; Pedroza-Islas et al., 1999). Independent of lycopene presence, the size of microcapsules obtained by spray-dryer was not uniform. Both, the freeze-dried $\beta-C D$ and lycopene- $\beta-C D$ complex (Fig. $1 \mathrm{c}$ and $1 \mathrm{~d}$ ) showed irregular structures of different sizes that eventually formed aggregates, with small $\mathrm{CD}$ fragments on the surface. Similar structures were observed by Pralhad and Rajendrakumar (2004) for freeze-dried quercetin and $\beta$-CD complexes. 
Influence of the encapsulation process on lycopene purity

The encapsulation using spray-drying process was responsible for the increase in the lycopene purity from 96.4 to $98.1 \%$ (\% area of all-trans-lycopene peak), measured by HPLC on $\mathrm{C}_{30}$ column (Fig. 2a). This increase was mainly due to $0.7 \%$ reduction of 9-cis- and 13-cis-lycopene areas and $0.3 \%$ of lycopene 1,2-epoxide one (Fig. 2b). Small amount of 15-cis-lycopene was only detected before spray-drying.

According to the HPLC analysis on $\mathrm{C}_{18}$ column (Fig. 3a), the purity of lycopene after inclusion and freeze-drying decreased from 97.7 to $91.3 \%$ (\% area of all-trans-lycopene peak), due to $5.2 \%$ increase in the 13-cis + 15-cis-lycopene peak area (Fig. 3b).
Despite the apparently high temperature used in the spray-drying process, the generation of a highly atomized spray provided a large surface area for the rapid evaporation of water. Consequently, the mean temperature of the drops was low enough, and the residence time in the drying chamber of the dried particles short enough, so that excessive isomerization and oxidation of lycopene was avoided. On the other side, despite the use of low temperature, the liquid method used for the inclusion process into $\mathrm{CD}$, took a long time, allowing lycopene to reach the isomer equilibrium since it was in solution, with a consequent increase of cis-lycopene.

The influence of spray-drying, as well as inclusion and freeze-drying processes on carotenoids purity have not been reported, so far.
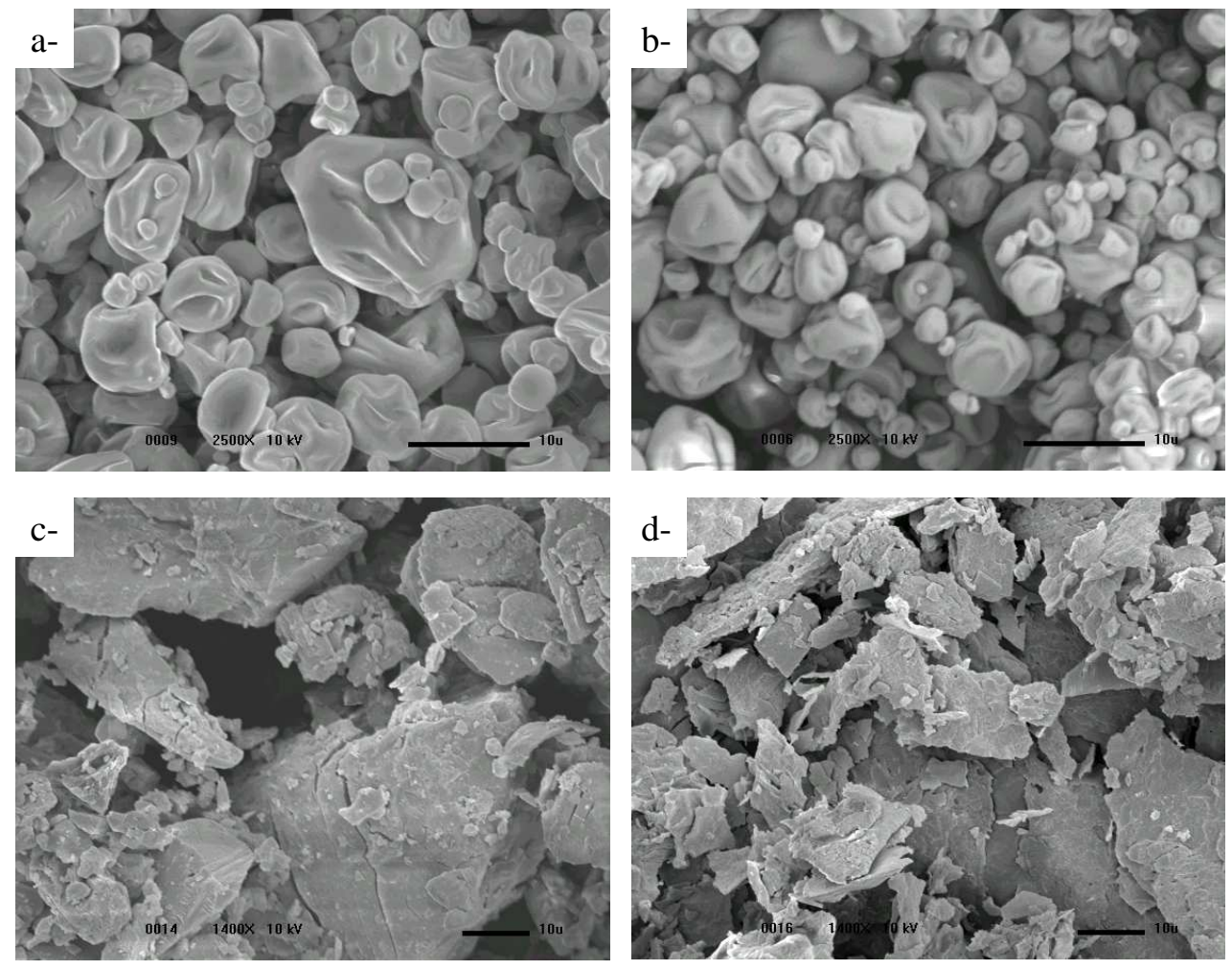

Figure 1 - SEM micrographs of microcapsules: a- spray-dried gum arabic:sucrose (8:2), b- spraydried gum arabic:sucrose $(8: 2)+$ lycopene, both with magnification of $2500 x$, cfreeze-dried $\beta-\mathrm{CD}$, d- freeze-dried lycopene- $\beta$-CD complex, both with magnification of 1400x. 


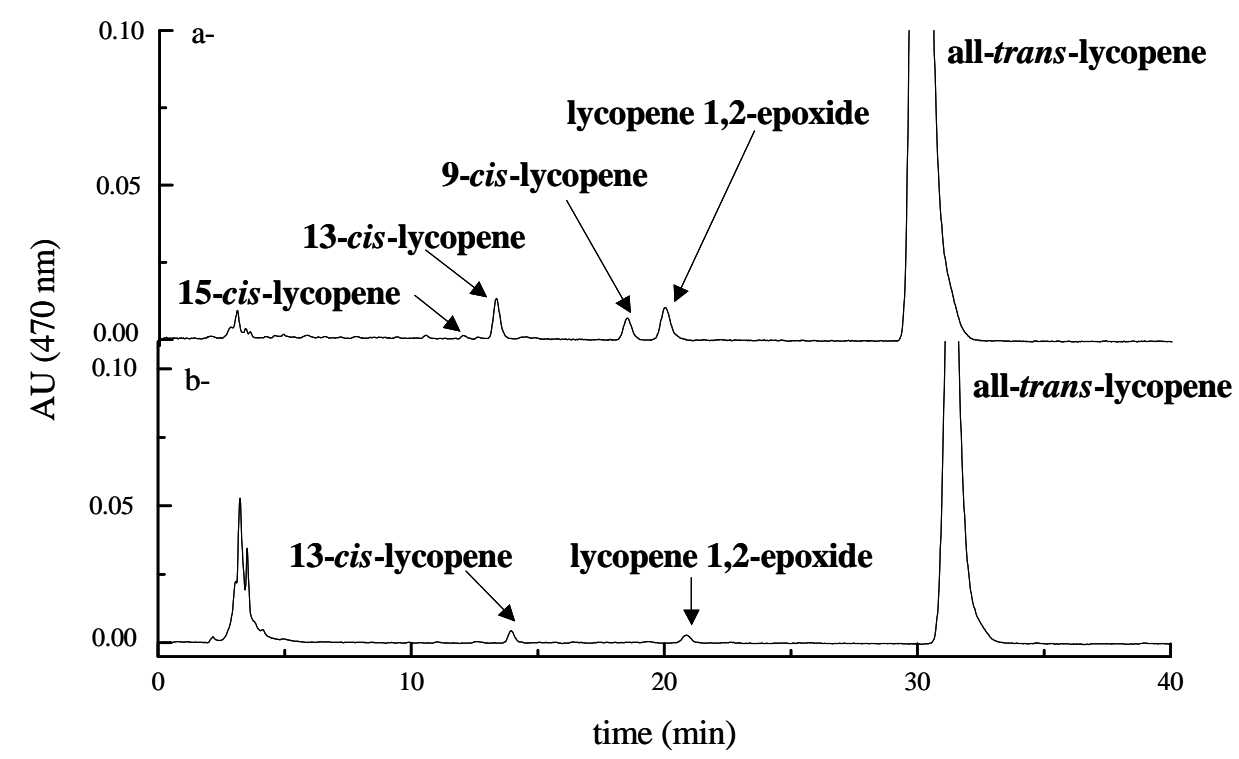

Figure 2 - Chromatograms obtained by HPLC of lycopene before (a) and after (b) spray-drying encapsulation. Chromatographic conditions: $\mathrm{YMC} \mathrm{C}_{30}$ column $(3 \mu \mathrm{m}, 250 \times 4.6 \mathrm{~mm})$ with $\mathrm{MeOH}(0.1 \%$ TEA)/TBME (1:1) as mobile phase at $1 \mathrm{~mL} / \mathrm{min}$ and column temperature set at $33^{\circ} \mathrm{C}$.

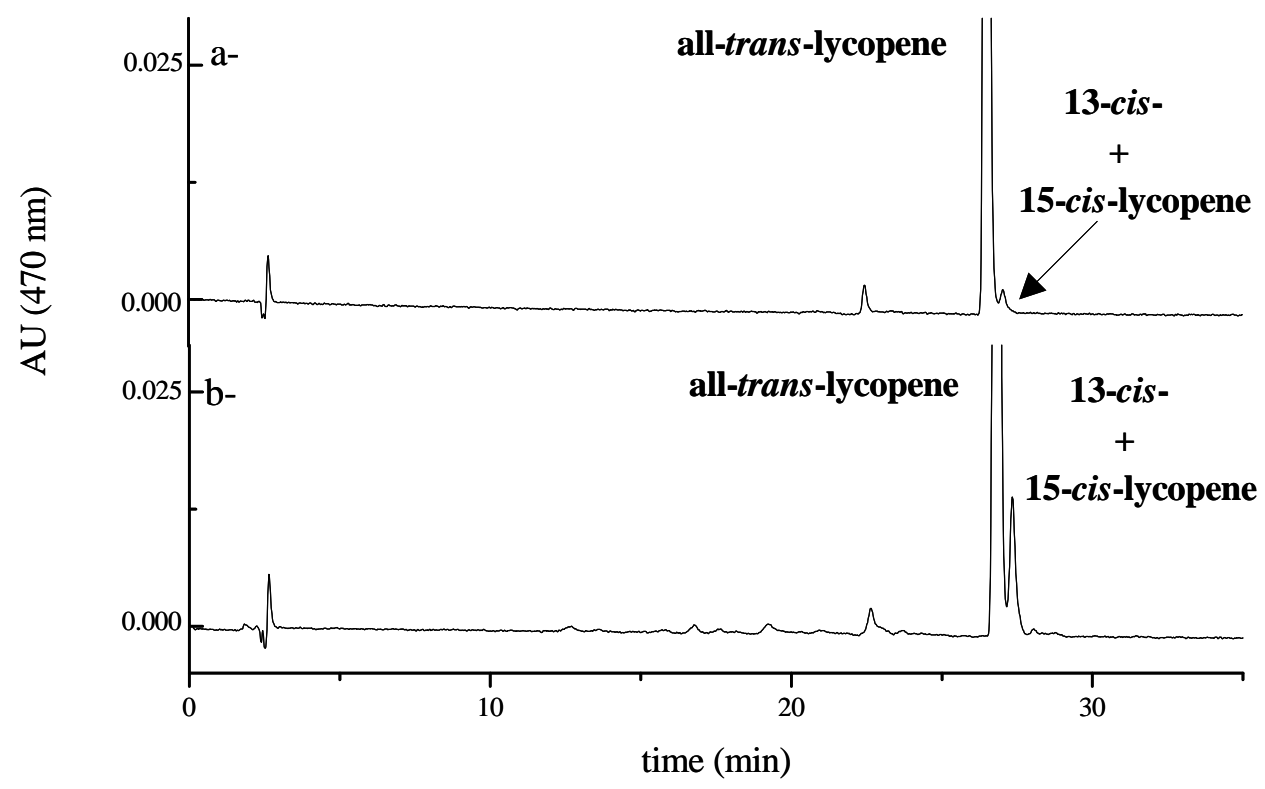

Figure 3 - Chromatograms obtained for HPLC of lycopene before (a) and after (b) inclusion with $\mathrm{CD}$ and freeze-drying. Chromatographic conditions: $\mathrm{C}_{18}$ Novapack $(4 \mu \mathrm{m}, 300$ x 3.9 $\mathrm{mm})$ column using as mobile phase a linear gradient of $\mathrm{MeOH}(0.1 \%$ TEA)/EtOAc/ $\mathrm{H}_{2} \mathrm{O}$ from 80:10:10 to 70:30:0 in $20 \mathrm{~min}$ at $1 \mathrm{~mL} / \mathrm{min}$ and temperature set at $29^{\circ} \mathrm{C}$. 


\section{ACKNOWLEDGEMENTS}

The authors thank Brazilian Foundation FAPESP and DSM Nutritional Products (Switzerland) for the financial support.

\section{RESUMO}

Técnicas de encapsulamento, como "spray-drying" e formação de complexos por inclusão com ciclodextrinas, vêm sendo avaliadas para viabilizar a adição de carotenóides em sistemas hidrofílicos e aumentar a sua estabilidade durante o processamento e estocagem. Portanto, o objetivo do presente trabalho foi obter licopeno encapsulado na forma de pó, utilizando processos de "spray-drying" ou de inclusão molecular com $\beta$-ciclodextrina (CD) seguido de liofilização. A eficiência do encapsulamento utilizando "spraydrying" variou de 94 a $96 \%$ e o rendimento médio foi de $51 \%$, com as microcápsulas apresentando indentações superficiais, porém sem falhas ou aberturas na superfície. A formação de complexo licopeno- $\beta-C D$ ocorreu apenas quando utilizada razão molar de 1:4, e estruturas irregulares de diferentes tamanhos que eventualmente formaram agregados, similares às da $\beta-\mathrm{CD}$, foram observadas após liofilização. $\mathrm{O}$ licopeno não complexado neste processo ficou em torno de $50 \%$. A pureza do licopeno (\% área do all-translicopeno) aumentou de 96,4 para 98,1\% após o encapsulamento, enquanto que a pureza do licopeno diminuiu de 97,7 para 91,3\% após complexação e liofilização. Os dois processos de secagem resultaram em pós rosa claro, secos e com bom fluxo.

\section{REFERENCES}

Barbosa, M. I. M. J.; Borsarelli, C. D.; Mercadante, A. Z. (2005), Light stability of spray-dried bixin encapsulated with different edible polysaccharide preparations. Food Res. Int., 38, 989-994.

Bertolini, A. C.; Siani, A. C.; Grosso, C. R. F. (2001), Stability of monoterpenes microencapsulated in gum arabic by spray-drying. J. Agric. Food Chem., 49, 780-785.
Britton, G. (1995), UV/visible spectroscopy. InCarotenoids: Spectroscopy, Vol 1B, ed. G. Britton; S. Liaaen-Jensen and H. Pfander. Birkhäuser, Basel. pp. 13-62.

Chen, B. H.; Tang, Y. C. (1998), Processing and stability of carotenoid powder from carrot pulp waste. J. Agric. Food Chem., 46, 2312-2318.

Davies, B.H. (1976), Carotenoids. In-Chemistry and Biochemistry of Plant Pigments, ed. T. W. Goodwin. Academic Press, London. pp. 38-165.

Desobry, S. A.; Netto, F. M.; Labuza, T. P. (1997), Comparison of spray-drying, drum-drying and freezedrying for $\beta$-carotene encapsulation and preservation. J. Food Sci., 62, 1158-1162.

Desobry, S. A.; Netto, F. M.; Labuza, T. P. (1999), Influence of maltodextrin systems at an equivalent 25 DE on encapsulated $\beta$-carotene loss during storage. $J$. Food Process. Preserv., 23, 39-55.

Giovannucci, E. (2002), Lycopene and prostate cancer risk: Methodological considerations in the epidemiologic literature. Pure Appl. Chem., 74, 1427 1434.

Hengartner, U.; Bernhard, K.; Meyer, K.; Englert, G.; Glinz, E. (1992), Synthesis, isolation, and NMRspectroscopy characterization of fourteen $(Z)$-isomers of lycopene and of some acetylenic didehydro- and tetradehydrolycopenes. Helv. Chim. Acta, 75, 18491865.

Lacrajan, I.; Dichl, H. A.; Socaciu, C.; Engelke, M.; Zorn-Kruppa; M. (2001), Carotenoid incorporation into natural membranes from artificial carriers: liposomes and $\beta$-cyclodextrins. Chem. Phys. Lipids, 112, 1-10.

Leach, G.; Oliveira, G.; Morais, R. (1998), Spraydrying of Dunaliella salina to produce a $\beta$-carotene rich powder. J. Ind. Microbiol. Biotechnol., 20, 8285.

Ling, S. M. O.; Passos, M.; Fontana, J. D. (2005), Bixin and $\alpha$-cyclodextrin inclusion complex and stability tests. Process Biochem., 40, 865-872.

Matioli, G.; Rodriguez-Amaya, D. B. (2002), Licopeno encapsulado em goma arábica e maltodextrina: estudo da estabilidade. Braz. J. Food Technol., 5, 197-203.

Matioli, G.; Rodriguez-Amaya, D. B. (2003), Microencapsulação do licopeno com ciclodextrinas. Ciênc. Tecnol. Alim., 23, 102-105.

McNamee, B. F.; O'Riordan, E. D.; O'Sullivan, M. (2001), Effect of partial replacement of gum arabic with carbohydrates on its microencapsulation properties. J. Agric. Food Chem., 49, 3385-3388.

Mele, A.; Mendichi, R.; Selva, A. (1998), Non-covalent associations of cyclomaltooligosaccharides (cyclodextrins) with trans- $\beta$-carotene in water: evidence for the formation of large aggregates by light scattering and NMR spectroscopy. Carbohyd. Res., 310, 261-267. 
Mele, A.; Mendichi, R.; Selva, A.; Molnar, P.; Toth, G. (2002), Non-covalent associations of cyclomaltooligosaccharides (cyclodextrins) with carotenoids in water. A study on the $\alpha$ - and $\beta$ cyclodextrin- $\psi, \psi$-carotene (lycopene) systems by light scattering, ionspray ionization and tandem mass spectrometry. Carbohyd. Res., 337, 1129-1136.

Mercadante, A. Z.; Steck, A.; Pfander, H. C. (1999), Carotenoids from guava (Psidium guajava L.): isolation and structure elucidation. J. Agric. Food Chem., 47, 145-141.

Mercadante, A. Z.; Egeland, E. S. (2004), Handbook of Carotenoids, ed. G. Britton; S. Liaaen-Jensen and H. Pfander. Birkhäuser, Basel.612p.

Nunes, I. L.; Mercadante, A. Z. (2004), Obtenção de cristais de licopeno a partir de descarte de tomate. Ciênc. Tecnol. Alim., 24, 440-447.

Nunes, I. L.; Mercadante, A. Z. (2006), Vantagens e desvantagens das colunas $\mathrm{C}_{18}$ e $\mathrm{C}_{30}$ para separação de carotenóides por CLAE. Rev Bras. Ciênc. Farmac., 42, 539-546.

Pralhad, T.; Rajendrakumar, K. (2004), Study of freezedried quercetin-cyclodextrin binary systems by DSC, FT-IR, X-ray diffraction and SEM analysis. $J$. Pharmac. Biomed. Anal., 34, 333-339.

Pedroza-Islas, R.; Vernon-Carter, E. J., DúranDomínguez, C.; Trejo-Martinez, S. (1999), Using biopolymer blends for shrimp feedstuff microencapsulation - I. Microcapsule particle size, morfhology and microstructure. Food Res. Int., 32, 367-374.
Pfitzner, I.; Francz, P. I.; Biesalski, H. K. (2000), Carotenoid:methyl- $\beta$-cyclodextrin formulations: an improved method for supplementation of cultured cells. Biochim. Biophys. Acta, 1474, 163-168.

Polyakov, N. E.; Leshina, T.V.; Konovalova, T. A.; Hand, E. O.; Kispert, L. D. (2004), Inclusion complexes of carotenoids with cyclodextrins: ${ }^{1} \mathrm{H}$ NMR, EPR, and optical studies. Free Radical Biol. Med., 36, 872-880.

Sheu, T. Y.; Rosenberg, M. (1998), Microstructure of microcapsules consisting of whey proteins and carbohydrates. J. Food Sci., 63, 491-494.

Van Den Berg, H.; Faulks, R.; Granado, H. F.; Hirschberg, J.; Olmedilla, B.; Southon, S.; Stahl, W. (2000), The potential for the improvement of carotenoid levels in foods and the likely systemic effects. J. Sci. Food Agric., 80, 880 -912.

Venkateswaran, V.; Fleshner, N. E.; Sugar, L. M.; Klotz, L. H. (2004), Antioxidants block prostate cancer in lady transgenic mice. Cancer Res., 64, 5891-5896.

Wagner, L. A.; Warthesen, J. J. (1995), Stability of spray-dried encapsulated carrot carotenes. J. Food Sci., 60, 1048-1053. 